\title{
Uses and community perception on the value and status of P. africana (Hook. F) Kalkm across Western Mau Forest
}

\author{
Gladys Chebet*, Paul K. Mbugua and Rebecca N. Karanja \\ Department of Plant Sciences, School of Pure and Applied Science, Kenyatta University, Kenya. \\ DOI: 10.29322/IJSRP.11.11.2021.p11905 \\ http://dx.doi.org/10.29322/IJSRP.11.11.2021.p11905
}

\begin{abstract}
The study investigated the uses of Prunus africana and community perception on the value and conservation status of the same tree across Western Mau forest. Four blocks were objectively selected for the survey. A socio-economic survey was conducted using structured questionnaires containing both closed and open-ended questions to determine community perceptions on the status of the tree under study. The data were mainly analyzed in form of proportions and variations between sites tested using chisquare statistics at $\mathrm{p}<0.05$. The survey revealed that the tree is used for herbal medicine, timber, fuelwood, charcoal burning, and agro-forestry development. The community largely believed that the current management of Western Mau forest is not the best and as such the tree was in danger. They further argued that most detrimental human activities were on the rise which is a reason for worry. Histograms, tables and graphs showed that there were differences in the perceptions across the age categories. The differences were further corroborated by results of inferential statistics. It can be concluded that $P$. africana is of great importance to the local community around Western Mau forest but the current management approach is not sufficient. A more pro-active management approach is therefore recommended.
\end{abstract}

Key words: Community, Use, Conservation, Prunus africana

\section{Introduction}

The African cherry ( $P$. africana) is a widespread tree in montane habitats of Africa, providing multiple uses for the peoples throughout its range. About 35 years ago, bark extracts were found to be effective in the treatment of prostate cancer (Benign Prostatic Hyperplasia) and therefore of high economic value (Ochwang'I et al., 2014). Currently, P. africana bark is entirely collected from the wild, although attempts at cultivation are underway in Kenya (Jimu, 2011). It has been the subject of several studies addressing several ecological and socio-economic aspects (Jimu, 2011; Cunningham, 2016; Das and Buchholz, 2019).

Anthropogenic destruction of forests and natural habitat fragmentation of forest population cover has increased and has now become a significant threat to biodiversity maintenance (Clasenet al., 2015).The most important striking changes in the ecosystems have been observed to be as a result of mans' interference through clearance, fire and grazing.The processes affect large areas of forest belts by degradation of the forest leading to loss of biodiversity (Cunningham, 2016).

Although Western Mau forest is protected by law, illegal exploitation of forest resources continues (Kiprotich, 2016), further degrading this habitat. In Kenya there was a $0.5 \%$ annual forest loss, comprising of $930 \mathrm{~km}^{2}$ loss between 1990 and the year 2000 (Ongugo et al., 2014).In Western Mau forest in Rift valley,human encroachment on the forest for agricultural land and forest products has resulted in wide spread deforestation,with the result that only a small fragment of intact forest remains. One species suffering from this increased pressure is $P$. africana.Information on the community perception, ecology, population structure and distribution of P. africana in Western Mau, Kenya is lacking. Periodic data collection on the status of endangered species such as P.Africana is very critical as an effective way of monitoring. P. africana is endangered across its range mostly due to harvesting of wild populations. In the Western Mau forest however, the driver is not known. This study focused on the uses of the tree and what the community thinks about the status of $P$. africana in Western Mau forest, as a first step towards understanding the current status.

\section{Materials and Methods}

\subsection{Study Area}

The research was carried out in selected sub blocks within Western Mau Forest block which is the fifth largest block of Mau Complex in the South Rift region of the Rift Valley Province of Kenya (Figure 1). It is located in Kericho County at an altitude of between 2000 and $2600 \mathrm{~m}$ above sea level; and between latitude $0^{0} 10^{\prime} 46^{\prime \prime} \mathrm{S}$ to $0^{\circ} 17^{\prime} 42^{\prime \prime} \mathrm{S}$ and longitude of $35^{\circ} 27^{\prime} 05^{\prime \prime} \mathrm{E}$ to $35^{\circ}$ 
39' 42" E. It is managed by Kenya Forest Service and covers about 22,712 hectares of indigenous forest. The study blocks were Sorget, Masaita, Kedowa, and Kerisoi.

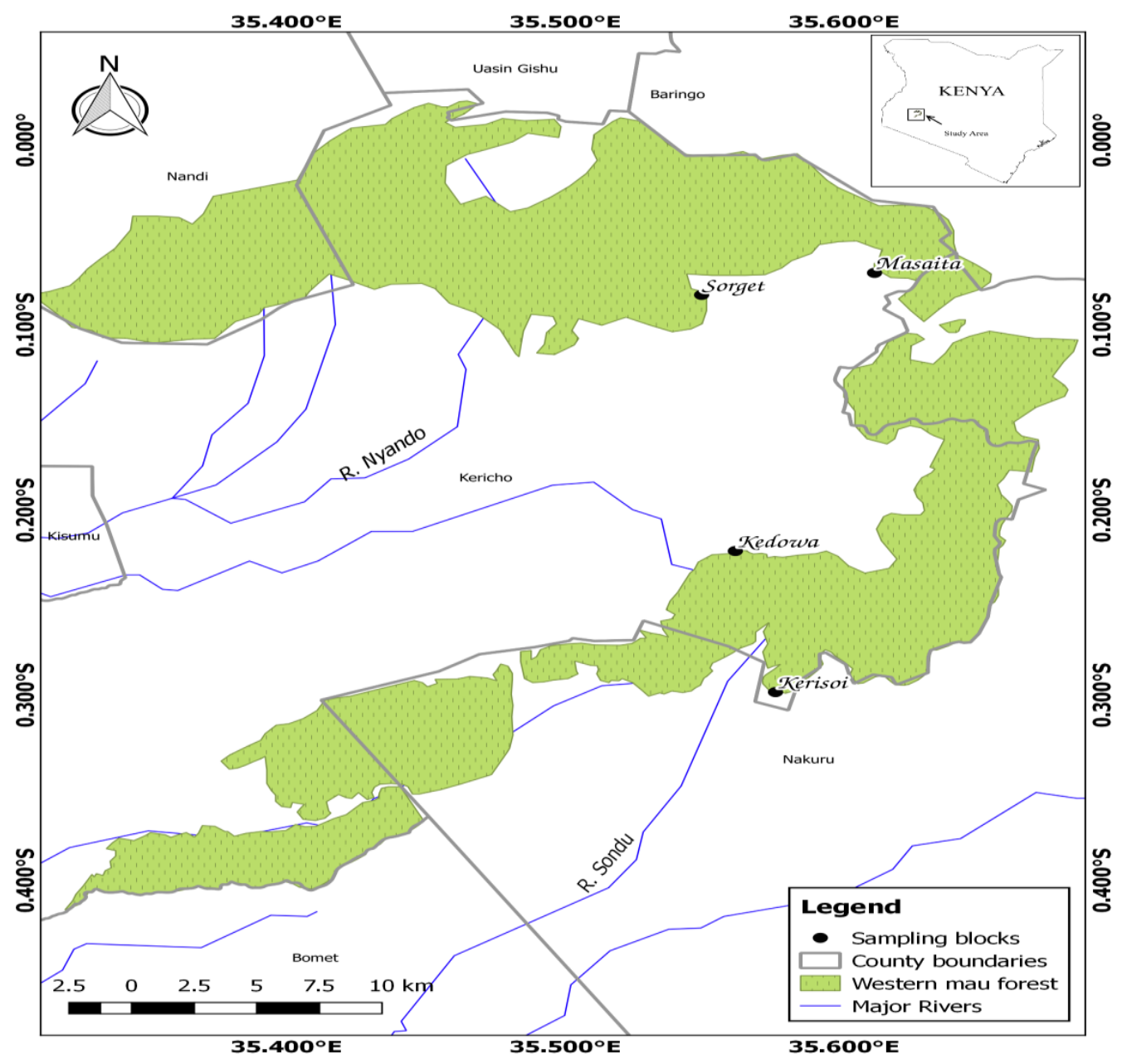

Figure 1: Map of Western Mau Forest and Locations of the Study Blocks.

\subsection{Sampling and sampling procedure}

Stratified sampling was used to lay a total of six transects and six quadrats in each of the forest blocks. Distances between 0 and $500 \mathrm{~m}$ were drawn between the successive transects and quadrats marked. In each of the 50x50m square quadrats, corners were marked using GPS coordinates for geo-referencing. Two quadrats were placed at the beginning, two at the middle and the remaining two at the end of the marked transect per sampling block.

\subsection{Data Collection and analysis}

From each block, respondents were also interviewed using structured questionnaires to determine their uses of the target tree and their perceptions on the factors affecting the tree. The respondents were selected objectively to represent the various groups in terms of age and economic status. Key informants such as herbalists and provincial administrators were also interviewed with separate set of questions. Photograph taking was also part of the ways of collecting data. This helped in capturing salient information about the study.

All the data generated were entered in excel spreadsheet for the purpose of storage and management. Qualitative data were converted into quantitative form and represented in form of proportions. The influences of human activities was tested using chisquare statistics at $95 \%$ confidence levels.

\section{Results}

This publication is licensed under Creative Commons Attribution CC BY. 


\subsection{Respondent Characteristics}

From the respondents interviewed, 53.3\% were males while the remaining $46.7 \%$ were females. On the age category, majority of the respondents were between 30 years and 40 years (39.17\%) while the lowest proportions were below 20 years and above 50 years respectively (Figure 2a).The results further showed that most of the respondents had completed secondary education followed by primary school graduates and middle level college graduates in that order while very few had university degrees $(5.5 \%)$ as shown in Figure $2 b$. The respondents were dominated by farmers, accounting for $45.2 \%$ followed by businessmen (27.5\%). Those in formal employment accounted for $16.8 \%$ while the rest were herbalists (Figure2c). On examining distances from homes to the forest, it was observed that over $60 \%$ of the respondents were within $15 \mathrm{Km}$ while only $16.3 \%$ lived more than $25 \mathrm{Km}$ away from the forest (Figure2d).
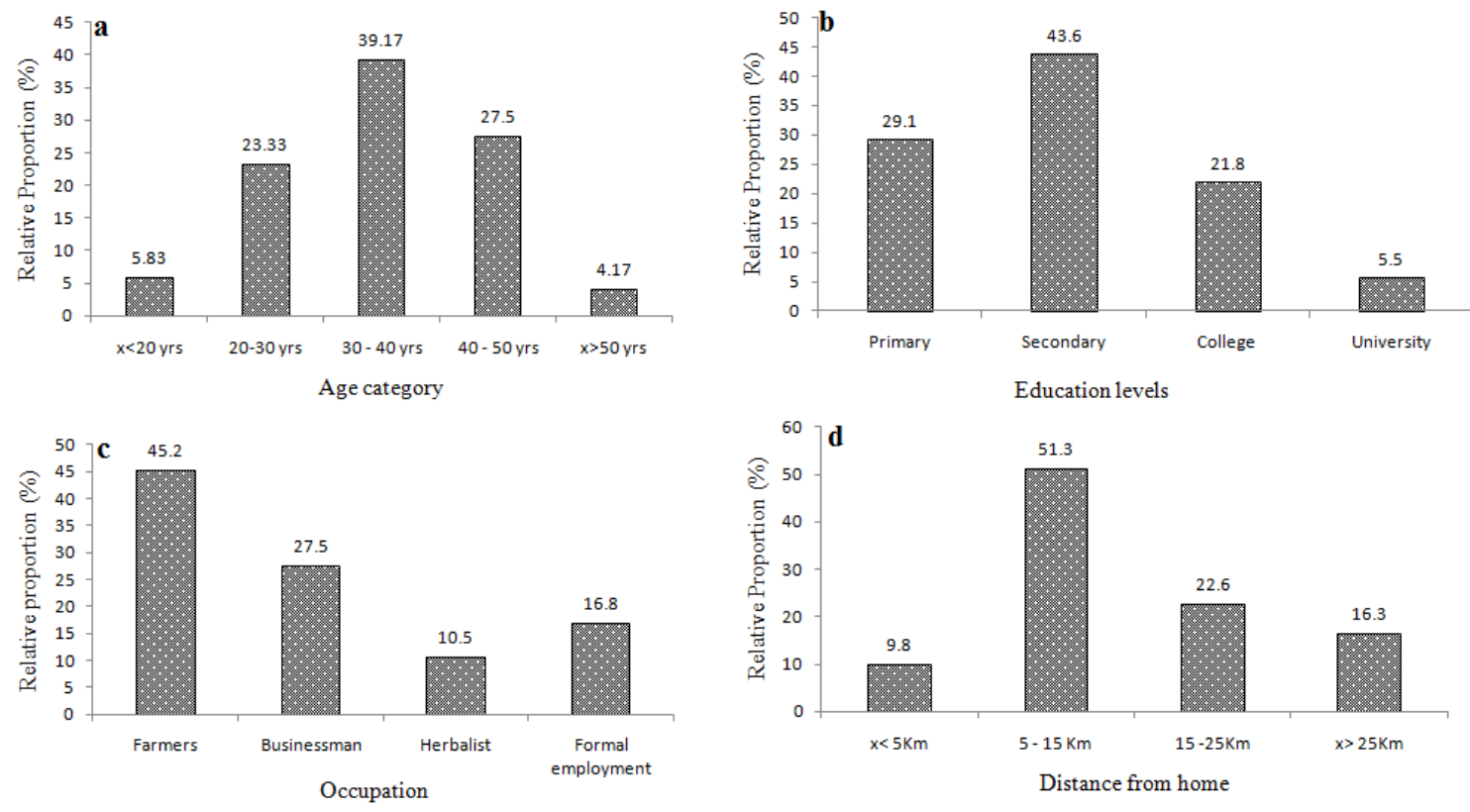

Figure 2: Characteristics of the respondents interviewed during the study

\subsection{Forest Management}

A large proportion of respondents of over $85 \%$ from western Mau forest have neither read nor discussed the contents of the current forest conservation and management act 2016 (Figure 3a). However, the few who reported to have read or discussed the act could not explain clearly the thrust of the act. As concerns forest management responsibility, $36.3 \%$ of the respondents were of the opinion that it's the role for both the government and local communities to ensure that the forest is well managed where as $31.2 \%$ and $26.8 \%$ thought it was the role of government and local communities respectively. The remaining $5.7 \%$ had no idea of who should manage the forest as shown in figure $3 \mathrm{~b}$.

While examining the role of the local communities in the conservation of Western Mau forest (Figure 3c), 58.1\% of the respondents are of the view that the community does not take an active role in the management of the forest. $35.6 \%$ of the respondents were of the opinion that the community plays an active role in the management. Some of the initiatives they pointed out included planting of highly targeted trees at home and regular sensitizations at local meetings. All the respondents however reported that the forest is of great importance to them and should not be destroyed to extinction. They were very concerned about the current state of affairs. In fact, only $8.7 \%$ were happy with the way the forest is currently being managed whereas over $10 \%$ were very disappointed at the current state of management of Western Mau forest (Figure 3d). They specifically pointed out political interference, compromised law enforcers, and unsustainable utilization due to lack of knowledge from the local community as the main reasons behind poor management. 

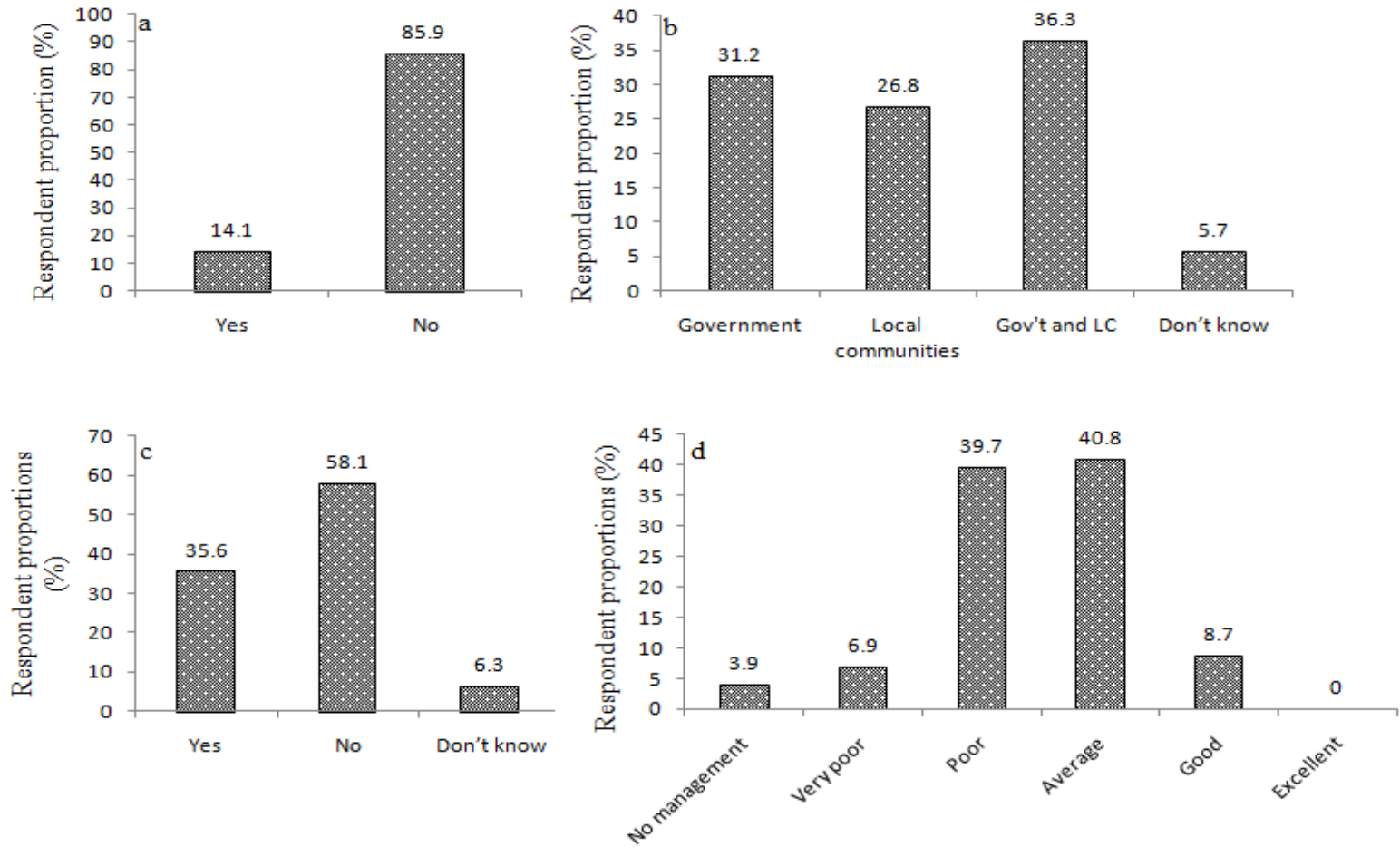

Figure 3: Community perceptions on the status of forest management (a-knowledge of the forest conservation and management act; $b$ - who is responsible for forest management; $\mathbf{c}$ - community participation in forest management; $d$ nature of current management system).

\subsection{Uses of Prunus africana}

Based on observation and interviews with the respondents, it was established that the community has five main uses for Prunus africana. These include medicinal purposes, agro-forestry, timber, fuelwood, and charcoal burning. A very large proportion of respondents $(93.3 \%)$ reported that they use the tree for medicinal purposes though they reported that they use different parts. Majority of them use the bark for the treatment of Benign Prostatic Hyperplasia, erectile dysfunction, male baldness, chest pain and inflammation, urinary tract disorders, kidney disease, wound dressing, and stomach upset. The leaves on the other hand were found to be useful in the improvement of appetite and treatment of genital infection.

Table 1: Uses of P.africana, parts used and respondent proportion for the use within Western Mau forest.

\begin{tabular}{l|ll}
\hline Use & Part(s) used & Proportion (\%) \\
\hline Herbal medicine & Bark, leaves, and roots & 93.3 \\
Agro-forestry & Seeds, seedlings, saplings & 15.8 \\
Timber & Stem & 28.3 \\
Fuel wood & Whole tree except leaves & 98.3 \\
Charcoal & Whole tree except leaves & 35.8 \\
\hline
\end{tabular}

\section{Observed human activities}

During the survey and site visits, a total of six human activities that impact on population, distribution and health of Prunus africana were observed. These include animal grazing, debarking, tree felling, $P$. africana seed collection, firewood collection, and charcoal burning. Other uses though not precisely related to the tree were picnics by people of youthful age, educational tours, and research.

Debarking, presumably for medicinal purposes had the highest number of occurrence with an average of 7 debarked trees per visit. It was further observed that $70 \%$ of the debarked trees died out, an indication that the process was not done in a sustainable and recommended manner. At least four new tree stumps were also observed within the forest every sampling expedition. Tree stumps are usually the best indicators of tree felling or logging though the purpose can hardly be deduced. Cattle, sheep and donkeys were the animals observed grazing within the forest. This could imply that the tree not only provide food to animals via its leaves but also 
provides favourable environment for animal pasture underneath. Seed and firewood collectors were also observed though not as frequent as grazing animals and freshly debarked trees. An average of one charcoal burning incident per visit was observed though the exact source of wood and tree type could not be ascertained since those doing the burning could not be found for interview.

On comparing the intensity of logging based on number of stumps and charcoal burning incidences between the blocks, it was observed that Kerisoi had the highest incidences where asKedowa recorded the lowest incidences (Figure 4). Out of all the charcoal burning incidences recorded within the study area, $47.3 \%$ were spotted in Kerisoi block whereas only $12.3 \%$ and $9.2 \%$ were observed in Masaita and Kedowa respectively. The same trend though with varying proportions was witnessed for number of stumps which was directly linked to logging.

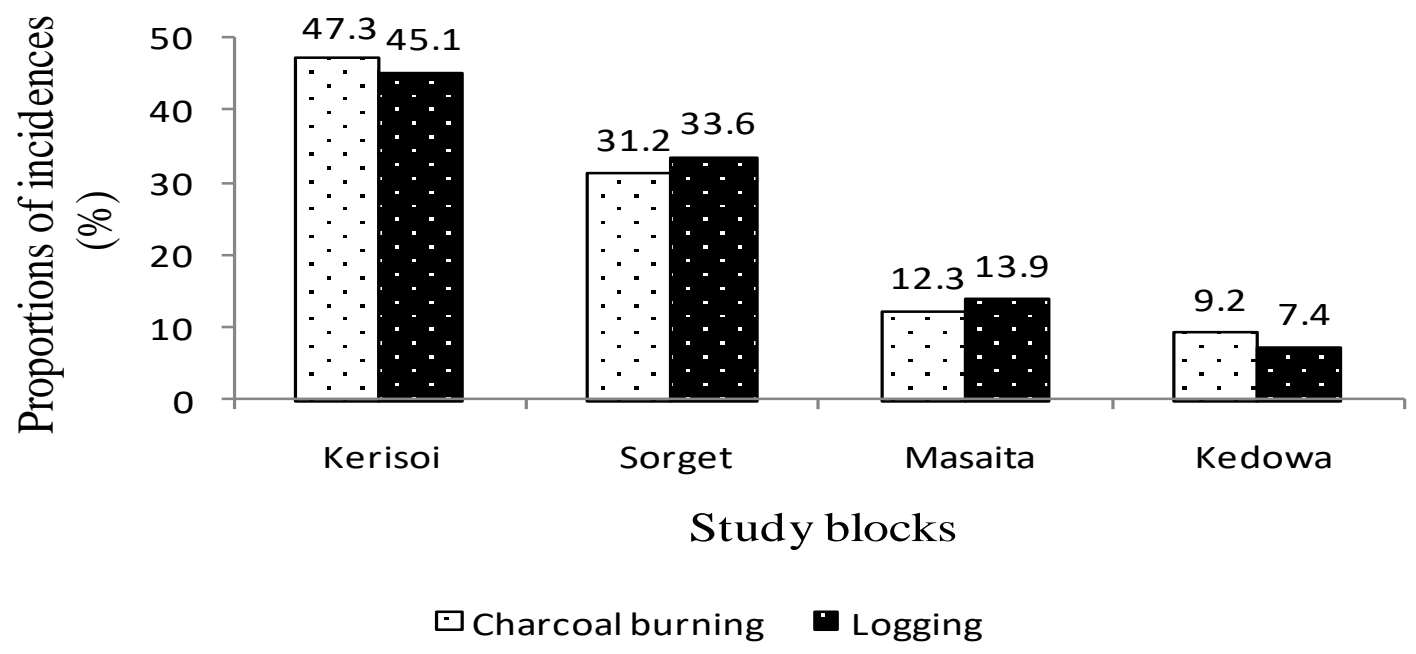

Figure 4: Incidences of charcoal burning and logging across the blocks during the study.

\subsection{Community perception on conservation status of Prunus africana}

When the respondents were asked of their perception on the conservation status of $P$. africana, they gave varied opinions (Table 2). Regarding the population density, majority of the respondents (73\%), especially those above 30 years were of the observation that the tree population density is very low compared to the last three decades. None of the respondents said it has not changed whereas $27 \%$ were non-committal since they were not around then. The respondents $(73.1 \%)$ further claimed that it was hardly possible to find the big sized trees currently as these were the targets for wood loggers. They were of the opinion that the average tree sizes have greatly reduced with majority of trees felled before attaining 30m height. A small proportion (14.3\%) gave a dissenting opinion, arguing that the average tree sizes have not changed. Interestingly, $2.4 \%$ argued that the average sizes have increased between now and the last three decades.

There was a consensusby most respondents that logging and felling of trees generally with $P$. africana included is very high and increases day by day despite government restrictions, with only less than $6 \%$ recording a different opinion. Slightly over $50 \%$ of the respondents were of the opinion that the rate and frequency of debarking has increased, whereas about $30 \%$ thought the frequency and the rate has not changed. None of the respondents was of the view that the practice has reduced while $12.2 \%$ declined to give a comment. Generally, the respondents were of the view that human presence in Western Mau forest has greatly increased for various reasons and they think this is a threat to the trees within the forest including $P$. africana.

Table2: Community perceptions on the status of $P$. africana within Western Mau forest

\begin{tabular}{l|llll}
\hline \multirow{2}{*}{ Indicators } & \multicolumn{4}{c}{ Community Perceptions (\%) } \\
\cline { 2 - 5 } & Increased & Not changed & Decreased & Don't Know \\
\hline Population density & 0 & 0 & 73 & 27 \\
Average tree sizes & 2.4 & 14.3 & 73.1 & 10.2 \\
Logging and tree felling & 93.7 & 0 & 2.5 & 3.8 \\
Debarking of prunus africana & 53.1 & 34.7 & 0 & 12.2 \\
Charcoal burning & 61.3 & 0 & 3.9 & 34.8 \\
Seed and seedling collection & 89.3 & 0.4 & 1.3 & 9 \\
\hline
\end{tabular}

This publication is licensed under Creative Commons Attribution CC BY. 


\begin{tabular}{l|llll}
\hline General human presence & 95.6 & 4.4 & 0 & 0 \\
\hline
\end{tabular}

\section{Influence of Age on Community Perceptions}

Results of this study revealed that there was a relationship between age of the respondents and their perceptions $\left(X^{2}=14.46, p\right.$ $=0.034)$. A clear shift in perception was shown across the ages with minimal or no overlap in perception between the age categories except for charcoal burning and debarking (Figure 5). Majority of those who did not know the variation in the status of the tree over time were below 30 years. The young, below 30 years of age, reported not to know of any change, the elderly (over 40 years of age) on the other hand reported negative change such as reduced density, reduced average tree sizes, increased debarking, increased logging, and increased charcoal burning. The middle age between 30 and 40 years, however reported both negative and positive change though others were of the opinion that there has been no change.

Majority of the respondents were of the opinion that the population density of $P$. africana has decreased over the past years, however, all those who had a different opinion were mainly below 30 years of age and did not know whether there has been a change or not (Figure 5a). Chi-square statistics further revealed significant relationship between the perceptions and the ages $\left(X^{2}=20.95, p=\right.$ 0.001) and grouped the respondents into two separate categories of age categories. Those over 40 years were thus shown not to differ in opinion among them but had different opinion from those below 30 years.

In terms of tree sizes, a relatively similar trend was observed with all the respondents aged over 40 years reporting that the average sizes has decreased while all those below 20 years did not know whether there has been a change or not (Figure 5b). Those between 20 years and 30 years had varied opinions though majority of them were of the perception that the average sizes had not changed. Inferential statistics showed that there was significant relationship between the age and the perceptions concerning changes in average tree sizes over time $\left(\mathrm{X}^{2}=110.98, \mathrm{p}=0.001\right)$. On pairwise comparison, age categories 30-40 years, 40-50 years, and above 50 years were found to have similar perception. The respondents were thus grouped into three categories i.e. those below 20 years, 2030 years, and above 30 years.

Just like population density and average size, community perception on the status of logging and felling of trees varied with age (Figure 5c). All those respondents over 30 years of age were of the opinion that the activity has increased with majority of the respondents between 20 years and 30 years agreeing with them. However, for those below 20 years old, majority did not know if there has been a change while others thought it had increased and some were of the opinion that the activity is on a decline. The influence of age on community perception concerning logging and tree felling was observed to be significant $\left(X^{2}=59.66, p=0.002\right)$.

Debarking was perceived to have increased across all the age categories though over $34 \%$ of the respondents spread across the age categories thought the intensity has not changed (Figure 5d). All the respondents of age over 50 years argued that the practice has increased greatly and currently people of all ages collect the tree bark as opposed to long ago when few elderly herbalist did debarking. Even though respondents from all the age categories were in agreement that debarking is in the increase, the proportion increased from young respondents to the older ones, same trend for those who thought it had not changed. Only respondents below 30 years of age did not know whether there has been a change. The respondent perception on the status of debarking over time was significantly influenced by age as shown by chi-square statistics $\left(X^{2}=43.34, p=0.001\right)$.

Charcoal burning (Figure 5e) and seed collection (Figure 5f) were perceived to have increased by respondents from all the age categories. Unlike other forest variables, a relatively large proportion were non-committal on the status of charcoal burning and said they do not know, the only variable where respondents over 50 years of age claimed not to know if there has been any change. As for seed and seedling collection, it was almost unanimous that the practice has increased and is destined to continue due to the fact that local administration are encouraging planting of indigenous trees in private farms. Chi-square statistics revealed that the perceptions on both charcoal burning and seed collection were also influenced by age of the respondents $\left(\mathrm{X}^{2}=11.93, \mathrm{p}=0.001\right.$ and $X^{2}=42.42, p=0.018$ respectively). 

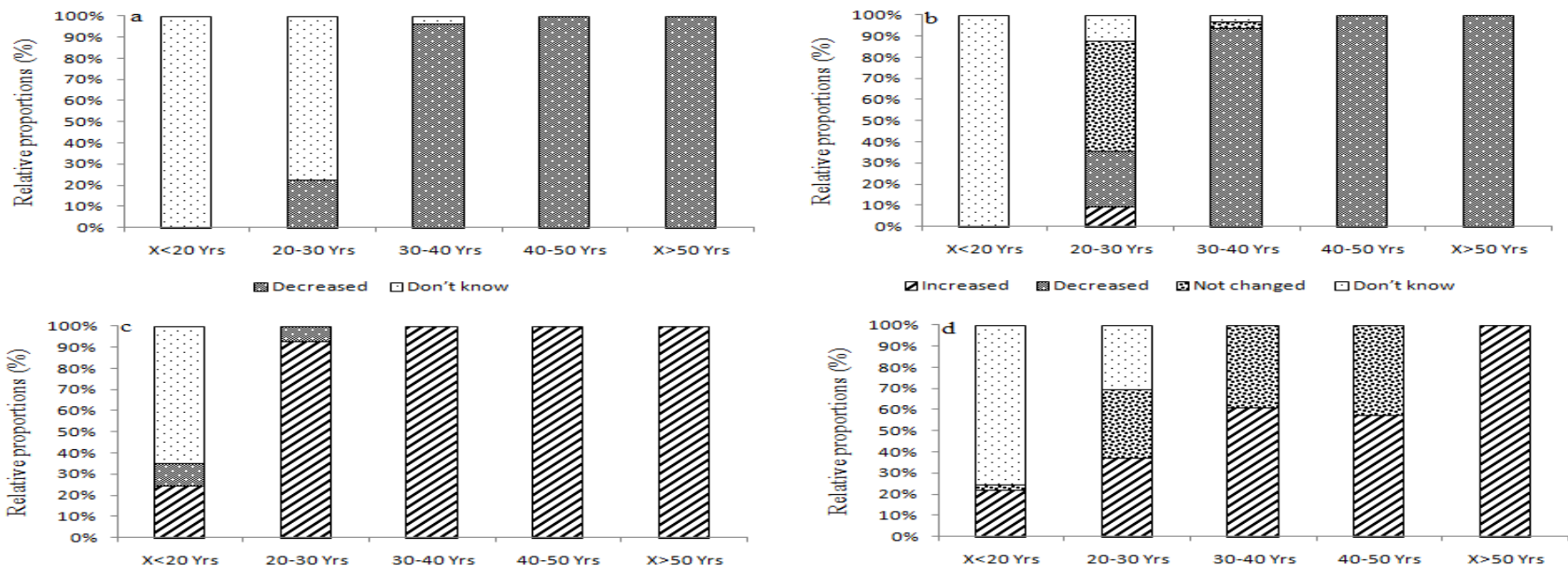

घincreased Decreased $\square$ Don't know
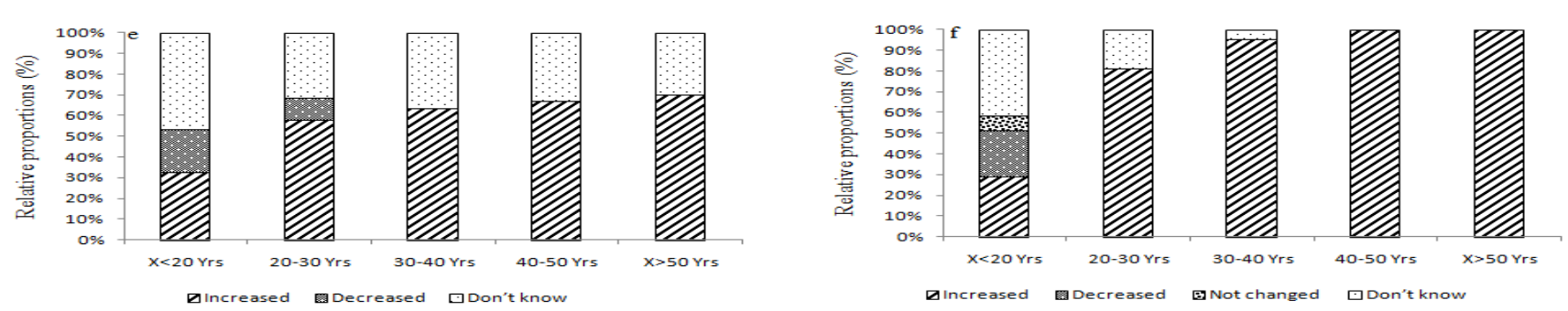

Figure 5: Influence of age on community perceptions (a- population density; b - average size; $c$ - felling and logging; $d$ debarking; $\mathrm{e}$ - charcoal burning; $\mathrm{f}$ - seed and seedling collection).

\section{Discussion}

From field observations and respondent interviews, it was established that the community has five main uses for the African cherry tree within Western Mau forest. These include medicinal purposes, agro-forestry, timber, fuelwood, and charcoal burning.Each of these activities affects forests and specific trees differently, and the magnitude of the effects will depend strongly on the methods employed locally, the forest type, and on other factors within and around the ecosystem. According to Sedano et al. (2016), human activities affect any or all the three major forest aspects which include the total forest area or cover, forest configuration, and forest structure and composition. In the event of a specific tree being targeted, the effects may be first realized on the target tree but this will eventually spread to the whole forest due to biodiversity interdependence.

During this study, it was observed that for medicinal purposes, the users harvest the bark, leaves, or sometimes the roots and seeds of $P$. africana for treatment and prevention of prostate cancer in men and retrieval of retained placenta in dairy animals. The part frequently used, however was the bark since it was perceived to be the most effective. The harvesting of the bark can be reckless or sustainable depending on the knowledge of the harvester (Kiprotich, 2016). Reckless de-barking has been reported to cause death to the affected trees (Amahowe et al., 2018). Results of field observations and respondent interviews further revealed that de-barking causes tree death thereby leading to reduced populations. This corroborates the findings of Stewart (2009) who recorded similar results. P. africana has the rare ability to regenerate its bark, as long as the vascular cambium is not destroyed (Guedje et al., 2016). In most cases, herbalists destroy the cambium thereby leading to death of the tree. From this study, the community was of the perception that majority of the de-barked trees eventually died which is in agreement with earlier findings (Amahowe et al., 2017; Nacoulma et al., 2017; Brockerhoff et al., 2017). It can thus be concluded that de-barking plays a major role in the declining population of $P$. africana in the Western Mau forest.

Logging of $P$. africana that was observed in western Mau forest was presumably for both charcoal burning and timber as kilns and tracks ferrying logs were observed. Logging has a primary effect on the population structure and size. It reduces the population density of the target species leading to dominance of smaller trees (Bolognesiet al., 2015), a finding that is in agreement with the results of this study where Kerisoi block recorded more stumps of $P$. africana and was dominated by smaller trees.

Other than population density and structure, there were secondary effects of logging such as increased access and resultant hunting which are important determinants of the status of forest biodiversity and the prospects for its preservation (Brockerhoff et al., 
2017). Logging which has a positive correlation with deforestation is a key driver to climate change (Dons et al., 2015) which partly explains the reasons behind changes in rainfall pattern around the Mau complex water tower. Felling of a big tree leads to death of several untargeted trees which not only opens the forest to further human presence but rapidly reduces forest cover (Chidumayo and Gumbo, 2013; Sedano et al., 2016). There is high preference for $P$. africana timber compared to other trees in the forest with the loggers targeting the bigger ones, but the felling of big ones leads to destructions of other untargeted tree species.

\section{Conclusion and Recommendations}

From this study it can be deduced that the tree of high value to the local community but the population is on a high decline.

The community faulted the current management system and asked for more pro-active approach. Activities such as de-barking, logging, and animal grazing which were the most common were perceived to greatly influence the distribution, abundance and population structure of the tree within the forest. The local community was further in agreement from the interviews that these are the main factors influencing the status of the forest. Based on these study findings, the following are recommended,

i. A comprehensive and all-inclusive training be organized and implemented on sustainable de-barking of $P$. africana as this activity is not likely to stop.

ii. Logging for any purpose and charcoal burning within and around the forest should be strictly regulated to save the tree from glaring extinction.

iii. Animal grazing during the post seeding period should be discouraged to allow seedling growth and transit to adult tree for the purpose of continuity. Trees have a predetermined cycle and likely to seed and seedling sprout at a predicted time of the year.

\section{References}

Amahowe, I. O., Orou G. G., Armand, K. N., Camille, P., Irié C. Z. and Bruno, H (2018). Functional traits partially mediate the effects of chronic anthropogenic disturbance on the growth of a tropical tree. Journal for environmental and evolutionary plant biology. Oxford University press.

Amahowe, O. I., Biaou, S.S.H., Natta, A. K., Balagueman, R. O. (2017). Multiple disturbance patterns and population structure of a tropical tree species, Afzelia africana (Leguminosae-Caesalpinioideae), in two contrasting bioclimatic zones of the Republic of Benin. Southern Forests: A Journal of Forest Science 80:95-103.

Bolognesi, M., Rembold, F. and Gadain, H. (2015). Rapid Mapping and Impact Estimation of Illegal Charcoal Production in Southern Somalia Based on WorldView-1 Imagery Energy Sustain. Dev. 25 40-9

Brockerhoff, E. G., Barbaro, L., Bastien. C., David, I., Forrester, B. G., Jose, R., Phil. O.B. L., Nicolas, M., Anne, O. H.T., Ian, D. T., Fons van der, Plas., Herve, J. (2017). Forest biodiversity, ecosystem functioning and the provision of ecosystem services. Journal of Biodiversity Conservation, 26:3005-3035.

Chidumayo, E. N., and Gumbo, D. J. (2013). The Environmental Impacts of Charcoal Production in Tropical Ecosystems of the World: A Synthesis. Energy for Sustainable Development, 17: 86-94. https://doi.org/10.1016/j.esd.2012.07.004.

Clasen, C., Heurich, M., Glaesener, L., Kennel, E. and Knoke, T. (2015). What factors affect the survival of tree saplings under browsing, and how can a loss of admixed tree species be forecast? Ecol. Model305:1-9.

Cunningham, A., Anoncho, V. F. and Sunderland, T. (2016). Power, Policy, and Prunus africana bark trade, 1972-2015.Journal of Ethnopharmacology, 178:323-333.

Das, K. and Buchholz, N. (2019). "Benign prostate hyperplasia and nutrition". Clin Nutr ESPEN. 33: 511. doi:10.1016/j.clnesp.2019.07.015. PMID $\underline{31451276 .}$.

Dons, K., Smith-Hall, C., Meilby, H. and Fensholt, R. (2015). Operationalizing measurement of forest degradation: identification and quantification of charcoal production in tropical dry forests using very high resolution satellite imagery Int. J. Appl. Earth Obs. Geoinf. 39: 18-27.

Guedje, N. M., Tchamou, N., Lejoly. J. (2016). Tree response to bark harvest: the case of a medicinal species, Garcinia lucida, as source of raw materials for plant-based drug development. Journal of Applied Biosciences 99:9476 - 9491.

Jimu, L. (2011). Threats and conservation strategies for the African cherry (Prunus africana) in its natural range.J. Ecol. Nat. Environ. 3: 118-130.

Kiprotich, R.L. (2016). An Assessment of Effects of Human Activities on Vegetation Characteristics in Chepalungu Forest; Bomet County, Kenya. MSc thesis, Kenyatta University-Kenya.

Nacoulma, B. M. I., Lykke, A. M., Traoré, S., Sinsin, B., Thiombiano. A. (2017). Impact of bark and foliage harvesting on fruit production of the multipurpose tree Afzelia africana in Burkina Faso (West Africa). Agroforestry Systems 91:565-576.

This publication is licensed under Creative Commons Attribution CC BY. 
Ochwang'i, D. O., Kimwele, C. N., Oduma, J. A., Gathumbi, P. K., Mbaria, J. M. and Kiama, S. G. (2014). Medicinal Plants Used in Treatment and Management of Cancer in Kakamega County, Kenya. Journal of Ethnopharmacology.151(3): 1040-1055.

Ongugo, P. T.; Langat, D.; Oeba, V.; Kimondo, J. M.; Owuor, B.; Njuguna, J.; Okwaro, G.; Russell, A. (2014). "A review of Kenya's national policies relevant to climate change adaptation and mitigation: Insights from Mount Elgon".

Sedano, F., Silva, J. ., Machoco, A. R., Meque, C. H., Sitoe, A., Ribeiro, N., Anderson, K., Ombe, Z. A., Baule, S. H. and Tucker, C. J. (2016). The Impact of Charcoal Production on Forest Degradation: A Case Study in Tete, Mozambique. Environmental Science letters 11(9): $247-261$. 